\title{
The Characteristics of the Aviation Industry
}

One major effect of the covid pandemic was, that it has not been easy to travel in the last two years. Many airlines have had to report losses. Despite massive state aid, they have had to reduce their fleet and personnel as well. There were also fewer new airplanes ordered. In our article, we would like to give a brief overview of the aviation industry. "The most dangerous worldview is the worldview of those who have not looked at the world." 3

The aviation industry is one of the most technology intensive sectors. These factors make this branch a global oligopoly, as there are few companies producing civilian and/or military aircraft on the market. The most important aviation manufacturing companies ${ }^{4}$ are Airbus SE (Fr), Boeing Company (US), United Technologies Corporation (US), General Electric Company (US), Safran S.A. (Fr) and the Empresa Brasileira de Aeronáutica S.A. The United States, France and Germany are at the forefront of aircraft production. The vast aeronautics companies are expanding their profile in the global market, dominating their market leadership. Their largest markets are the US, Asian countries, and Western European countries.

The aviation sector grew by 3.1 percent annually between 2015 and 2019, reaching USD 342.4 billion by the end of 2019 , and this huge pace fell by 14 percent in 2020 due to the halt and closures caused by the COVID pandemic, so this industry closed last year with 296.1 billion USD. Airbus SE, one of the world's leading airline, has chosen the European Company ${ }^{5}$, which is the single, supranational stock corporate format of the European Union, while Boeing is the largest competitor in the form of an American company group. They both have received significant state support.

The race for the conquest of space is huge. American spacecraft landed on Mars; Chinese spacecraft collected rock samples on the moon. These two largest aircraft manufacturers have joined the space industry too, building bigger and bigger part on the research, developing new technologies. This year the U.S. and EU finally agreed ${ }^{6}$ on a five-year ceasefire to their 17 year-long trade disputes over subsidies for the plane makers Airbus and Boeing, with suspending of all retaliatory tariffs and to allow continue granting Airbus "repayable launch investments", effectively credits to develop new airplane models. Until now, France, Germany, the U.K., and Spain have not published details of contracts under which they grant Airbus "repayable launch investments", however Washington also grants indirect aid to Boeing under secret defence contracts. The dispute escalated with the introduction of punitive tariffs on

\footnotetext{
1 Economist, worked for the European Commission's Academic R\&I and Research Organisations as a BBT, president of Pact for Youth Hungary 2 Economist, currently PhD student at the Faculty of Law at the Károli Gáspár University of the ReformedChurch, supervisor: Dr.Zsolt László Becsey, senior research fellow *** This working paper is the English Summary of the Article: AIRBUS SE VERSUS BOEING COMPANY - TECHNOLÓGIA-INTENZÍV LÉGIVERSENY http://humanexchange.hu/site/uploads/file/HISZ_2021_1.pdf

3 ,Die gefährlichste Weltanschauung ist die Weltanschauung derer, die die Welt nicht angeschaut haben.“ (Alexander von Humboldt)

4 The Business Research Company, 2020

5 The European Company (Latin: Societas Europaea, SE) aims to facilitate the merger of companies within the Union and cooperation between companies. In fact, the SE allows the company to continue its business activity in different European countries within a single regulatory framework (EUR-Lex - 32001 R2157 - EN - EUR-Lex (europa.eu))

6 ec. europa.eu/commission/presscorner/detail/en/ip_21_3001
} 
imports from the EU, and the Europeans reacted with special levies on imports from the USA. Until recently, customs duties hit exports worth about EUR 11.5 billion a year. The agreement was made with the Biden administration in June 2021 also helped the US and the EU to act jointly against China's 'non-market' practices in the aviation industry, which can have positive aftermaths on the future business prospects of Airbus and Boeing as well.

\section{Airbus SE}

Airbus is a typical example of a European company; it is a multinational aerospace corporation which one is present in several European Member States and in many countries around the world. The parent company is in Leiden ${ }^{7}$, in the Netherlands, but its Headquarters is in Toulouse (Airbus S.A.S.), France. Its activities include 70 development units and manufacturing sites in Europe ${ }^{8}$, mainly France, Germany (29 sites), the United Kingdom ${ }^{9}$ and Spain, as well as Romania, Poland, Finland, Turkey, Russia, and soon in Gyula, Hungary, but it is also present in several non-European countries (35 representations), mainly in the United States, China, and India. The group employs nearly 130 thousand people in 140 countries. It is listed on the German stock exchange (DAX) and is traded under Aerospace classification on Paris Stock Exchange. The currently earnings per share according to the company disclosure stays by 0.38 .

finance.yahoo.com/news/spotlight-airbus-se-epa-air

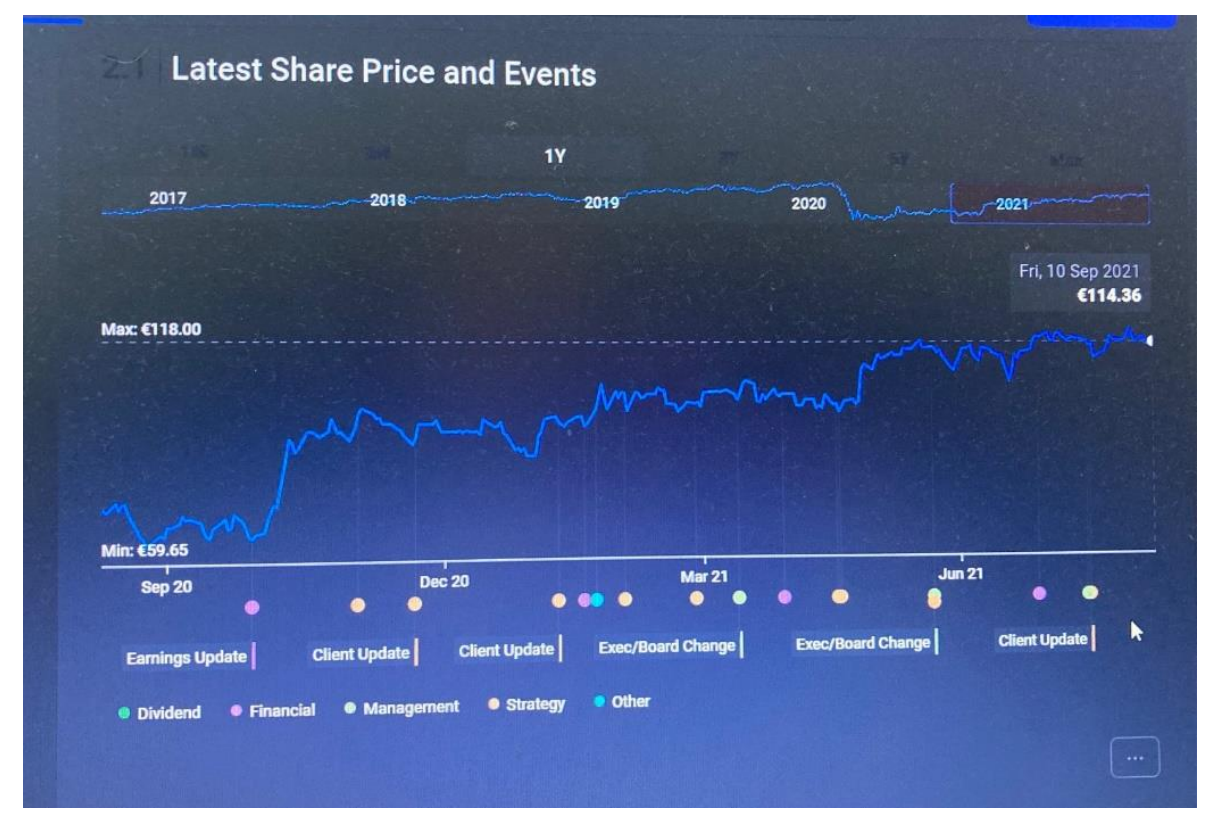

The main profile of Airbus is designing civilian and military aircraft, the production of aviation-related equipment and the worldwide sales of aircraft.

\footnotetext{
7 Board of Dirtectors Airbus SE Mendelweg 302333 CS Leiden The Netherlands, Chairman:Mr René Obermann 8www.airportal.hu/2022-ben-indulhat-az-airbus-helikopteralkatresz-gyartas-gyulan/

Airbus would have cost Airbus more than a billion euros a 9 week if there had not been a treaty between the EU and the United Kingdom, so it would have had to close the factories there. The company employs 14, employees $\quad$ in its factories in westem England.www.assets.publishing.service.gov.uk/government/uploads/system/uploads/attachment_data/file/948119/EU UK_Trade_and_Cooperation_Agreement_24.12.2020.pdf www.gov.uk/government/publications/agreements-reached-between-the-united-kingdom-of-great-britain-and-northern-ireland-and-the-european-union
} 


\section{Corporate structure of Airbus - European Company}

According to Regulation No 2157/2001 of the European Community of the European Council, the European Company is a form under the European law. An SE can be created in several ways: merger, establishment of a European holding company, creation of a European subsidiary, transformation, and outsourcing. The minimum amount of the SE's subscribed capital is 120 thousand EUR.

\section{Divisions of Airbus}

The predecessor of Airbus SE was the European Aeronautic Defence and Space (EADS) founded in 1970. It is the hundred-percentage owner of the Eurocopter SA, founded in 1992. In the meantime, EADS has grown to be Europe's largest aviation and aerospace group and in the world is the second largest defence group since 2018. Its annual turnover exceeds 63.7 billion EUR. Starting in 2014, the group took over the name of its subsidiary and started operating as Airbus Group N.V., and on 27 May 2015, the General Assembly announced that the company would take the form of European company law (SE) and would continue to operate as Airbus Group SE. This change announced with effect from 2 June 2015. In 2017, Airbus Commercial Aircraft (Airbus S.A.S.) merged into Airbus Group SE and started to operate as Airbus SE. The company has several subsidiaries (Premium Aerotec, Stelia Aerospace, Airbus Transport International, Elbe Flugzeugwerke), joint ventures (ATR, Daher Airplane, Tarmac Aerosave) and divisions (Airbus, Cassidian, Astrium, Eurocopter) located in Europe and around the world. Airbus Group Innovation (AGI) is responsible for research and development.

\section{Ownership Allocation of Airbus (macroaxis.com)}

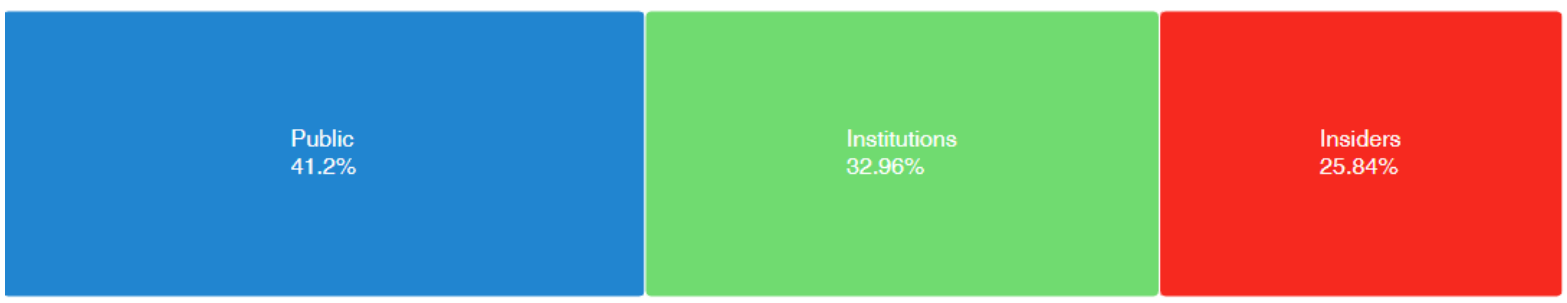

Civil aviation manufacturer Airbus S.A.S.

Civil aviation production takes place within the French Airbus S.A.S, with aircraft produced in Toulouse, France and Hamburg, Germany. The form of the company has been a simplified company under French law since 2001: "S.A.S.” (Société par Actions simplifiée).

Airbus Defence and Space Unit for Defence and Space

Spartan Airbus Military, Astrium and Cassidian merged into Airbus Defence and Space, based in Munich. The product portfolio includes the development of military aircraft (Eurofighter Typhoon, Airbus A400M, Airbus A330 MRTT,_Airbus C-295 Persuader), Satellites and Orbital Systems, commercial carrier rockets (ArianeGroup), controllable missiles (Lenkflug Circuits, MBDA), defence and countermeasure systems, security solutions and communication technologies. 
Airbus Helicopters Manufacturer of helicopters

The predecessor of Airbus Helicopters until 2014 was the Eurocopter, which founded in 1992. The Airbus Group is a German French-Spanish subgroup. The company has been the world's number one private and semi-state helicopter manufacturer since 2009, with an annual turnover of over 4.6 billion EUR. It has 18 subsidiaries worldwide. He sells private and military helicopters in 140 countries around the world, and the number of clients is close to three thousand. It employs 15600 people.

\section{Operational Structure of the Airbus SE}

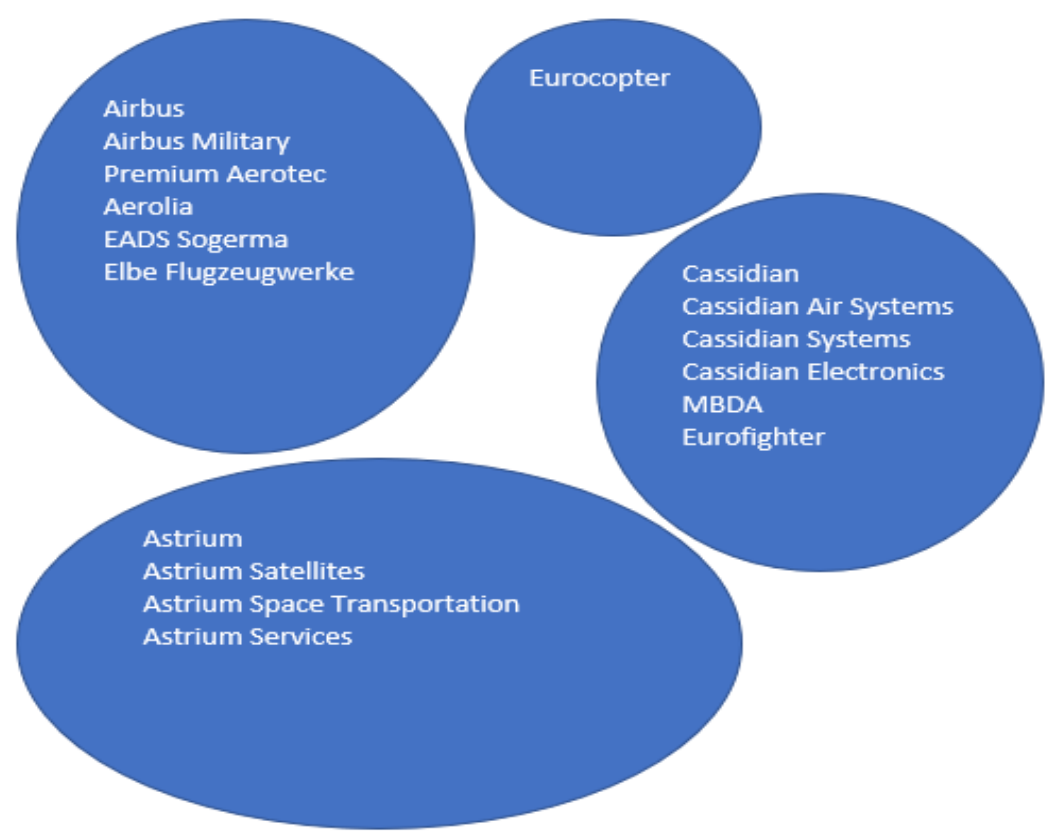

Source: Airbus.com

\section{Future of Airbus SE}

Airbus is a very diverse European group with significant global influence and is a company empire with long-term plans and strategies to reduce noise, carbon dioxide and nitrogen oxide emissions (Flightpath 2050). The Group was the first airline to receive ISO 140001 certification in January 2007. Participates in environmental programmes aimed at increasing the use of renewable energy sources and fuels (Algae, the development of biofuels, Zeroe).

Due to the covid crisis and the rivalry with the American Boeing (which receives more state aid than the European company), Airbus continued to receive significant orders in 2020, although only 566 jets were delivered to customers instead of the planned 880 aircraft, and last year was significantly below the record year of 2019, when 863 aircraft were delivered. Airbus delivered 40 jets in August 2021 to bring supplies of its new jets to 384 since the start of the year, remaining broadly on course to meet an annual goal of 600 deliveries. Hungary's Wizz Air is in negotiations with Airbus over the purchase of at least 100 more narrowbody jets, however this deal not yet announced. Occurred of the pandemic, they were forced to reduce their production, and according to the original plan the company's restructuring should have affected 15 thousand jobs. Thanks to the state opportunity, offered by short work (Kurzarbeit), there was no drastic redundancies. The current demand for labour is expected to increase probably only in the next years. 


\section{Boeing}

\section{Company Formation Regulation in the US Association (USA)}

Each US state has different regulatory environments in terms of corporate requirements, taxation, and other types of detail regulation, but the corporate management framework can be seen as much more unified than the European system. With the adoption of relevant federal laws of 1933 and 1934 (Securities Act of 1933, Securities and Exchange of 1934), amended by the Sarbanes-Exley Act 2002 and the Dodd-Frank Wall-Street Reform and Consumer Protection Act, the entire territory of the US has the same forms of procedure in terms of company formation, governance, and other forms of administrative procedures. The U.S. Constitution allows companies to register a head office in any state of the United States, regardless of the physical address of its head office. As federal laws govern the basic regulation, there is a kind of transparency and coherence across the US that provides higher predictability and lower administrative costs compared to companies registered in the EU. In terms of public competences, the desirable level of some local tax forms, existing infrastructures and incentive schemes can make some countries more attractive to their investment environment. Thanks to these factors, Boeing is present in several U.S. states, thus maximizing the potential and optimum taxation within US territories (Boeing, 2021). There was prohibited State aid for Boeing, thus placing its main competitor, Airbus, at a disadvantage. For this reason, the World Trade Organization (WTO) has authorized the EU to impose penal duties for USD 4 billion (EU Commission, 2020).

\section{The Story of Boeing}

Boeing's story dates to 1916, when William E. Boeing founded the Aero Products Company shortly after Conrad Westervelt developed a single-engine, double-seat waterplane, B\&W. In 1917, the company was named Boeing and was listed as the Boeing Airplane Company, which played a significant role in the production of military aircraft during World War I and the 20s and 30s. He was one of the most important suppliers of the U.S. Army. At that time, the company underwent a significant expansion, which combined airmail services, aircraft production (and all its processes) and other air transport operators with various acquisition transactions. By merging (and acquisitions) several major companies, United Airlines was created, which, under the Air Mail Antitrust Act of 1934, had to become three separate companies: Boeing Airplane Company, United Aircraft Corporation (now United Technologies Corporations) and United Airlines. Boeing was successful in selling military aircraft, but remained behind Douglas and Lockheed, its main rival in the sales of commercial civilian passenger aircraft.

Number of employees per segment

January 1,2021 Number of employees within the group

$\begin{array}{lllll}\begin{array}{l}\text { Commercial } \\ \text { aircraft }\end{array} & \begin{array}{l}\text { Defence, } \\ \text { space }\end{array} & \begin{array}{l}\text { Global } \\ \text { services. }\end{array} & \begin{array}{l}\text { Boeing } \\ \text { Capital Fund }\end{array} & \begin{array}{c}\text { Corporate total } \\ 34,624\end{array} \\ 15,033 & 17,645 & 73,712 & \mathbf{1 4 1 , 0 1 4}\end{array}$

Source:(Boeing, 2021)

To overcome this disadvantage, he developed his first transatlantic jet passenger plane to revolutionize transatlantic commercial passenger transport in 1958. After that, Boeing's economic success story culminated in the release of the 747 "Jumbo jets" in 1970. As a result of this development, the company was almost bankrupt, but the efficiency resulting from the 
high capacity of the new plane put the company in a monopoly position in the transatlantic flight segment. Meanwhile, the company successfully acquired the world's largest helicopter manufacturer, the Boeing Helicopters, as well as the development of the NASA's first Moon satellite, as well as its success in intercontinental ballistic missile production. The company's success story lasted until the 2000s, when the (irregular) state aid competition with Airbus SE began between European countries and the US, and then a fall in demand from high oil prices and economic crisis in 2008, which the company wanted to address with the 787 model. Due to the tragic events of the Boeing 737 MAX aircraft $(2018,2019)$, significant errors caused even more press coverage and a drop in demand.

\section{Boeing 787 orders (blue) and transfers (green) (cumulative figure)}

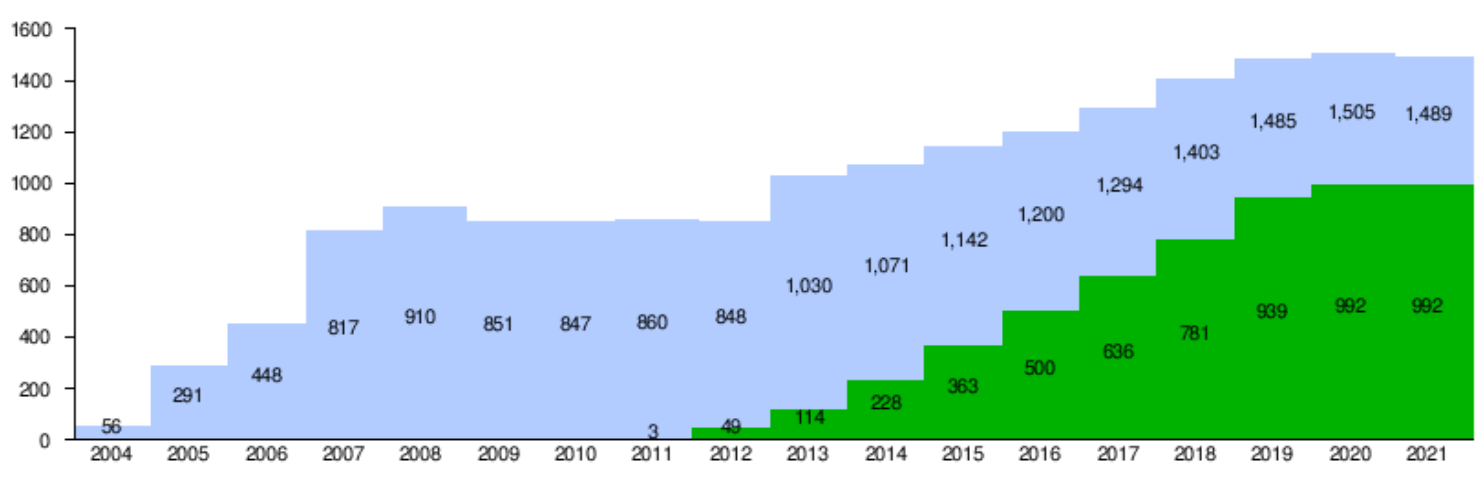

Source:(Boeing, 2021)

Due to the problems encountered, the development of type 787 consumed 32 billion USD, the return of which, according to preliminary calculations, would turn breakeven after the sale of approximately 1300 to 2000 aircrafts (Boeing, 2021). The US-China trade war also contributed negatively to the company's result, as China is one of the most dynamically developing markets in the world, (Martec Group, 2021) as well as a significant number of orders cancelled due to the COVID pandemic. Based on the settlement of shares, Boeing returned to the 2017 quotation rate, which represents a $268 \%$ increase compared to its local minimum on 16 March 2020 (Yahoo Finance, 2021).

\section{The corporate structure of Boeing}

The Boeing Company `s headquarter is in Chicago, Illinois, with a current market capitalization of 149.31 billion USD and an estimated total value of 188.73 billion USD. The expected annual gross profit level of the company -1.69 billion USD (and its result - US $\$ 11.9$ billion) ended with a loss in 2020. In December 2019, Boeing employed 143,000 employees in 50 states of the USA and employs around 1 million related workers through its suppliers. In 2021, the number of directly employed workers decreased to around 141,000, which the group intends to further reduce to 130.000 by the end of 2021. Boeing operates in four segments: Commercial aircraft production; Defence, space, and security; Global Services and Boeing Capital Fund. Commercial aircraft manufacturing includes passenger aircraft such as transport, auxiliary machinery, and aircraft. The defence, space and security segment undertakes a significant part of research, development (R \& D) activity, the development and manufacture of human and drone military machinery and systems, intelligence, and defence systems (development and manufacture of missile systems, control, computing systems, cyber and IT systems, satellites and other government and commercial orbital systems and space research systems and equipment). 
The global service segment offers systems and products such as the supplier network and logistics management and maintenance, training systems and related services. The Boeing Capital Fund expands its service segments with financial engineering instruments (lease, loan constructions, investments, operation). Regardless of the above reasons, Boeing's strength has always been the strategic importance of innovation.6. In 15, the company became the most innovative company in the industry, with more than 15,600 patents and 11 research and development centres worldwide. Through its regional headquarters outside the United States, the company ensures that local needs are considered and fully satisfied, which accounts for 70 $\%$ of the company's income. It has partners from around 150 countries around the world, employs people in 65 countries around the world.

Boeing in the World Source:(Alsatom, 2021)

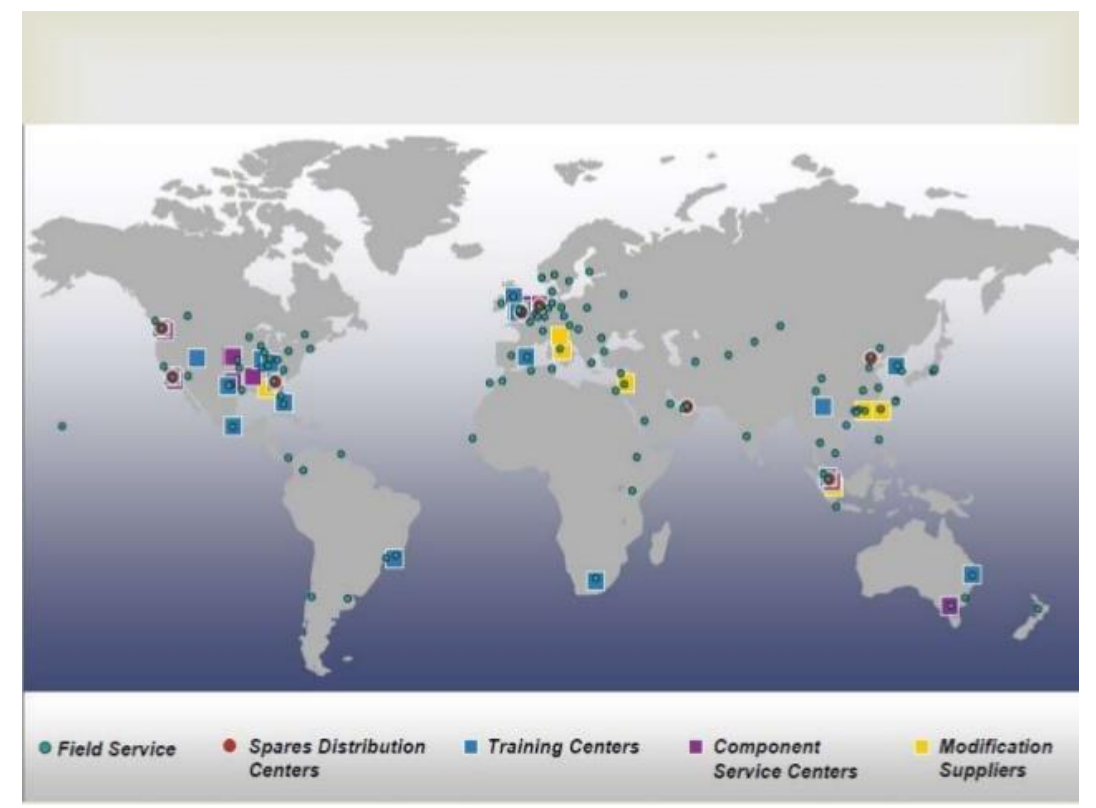

Future of the company and its business policy

The fluctuations in recent years have driven Boeing's share price significantly, but that effect of US risk hunger and unprecedented financial stimulus to deal with the pandemic is likely to lead to further positive uptakes in corporate financial indicators from the actual value and performance of the company. The last year has caused significant problems in the company's liquidity, which is forced to slow down aircraft production due to the covid pandemic. In the following years, the focus will be on medium-sized aircraft production (NMA) $(9300 \mathrm{~km}$ range), where Boeing wants to regain its market advantage, which it could keep with the 757, $767 \mathrm{~s}$, but is now taken over by Airbus A321neo (Hemmerdinger, 2021). The future is unpredictable from an economic point of view due to unprecedented government support programmes (and indebtedness). The protracted restrictive measures imposed by COVID, the short-term increase in market activity after expected opening (and probable unleashed inflation), the volatility of stock exchange paper prices (real value of the market). However, the company's business policy places great emphasis on long-term developments, so the next major product release is expected between 2030-2031. Since it is one of the largest employers and most important exporting companies in the US, it is expected that additional State aid will be granted if necessary. 


\section{Competition for the Conquest of Space - Arrangements}

Space is once again in the focus of the great powers of the world. The nations of the world have embarked on a new space race with enormous ambitions (USA - in 2024 the first female moon landing. 2021-2027 new European space strategies were adopted by the European Council. China in 2020 brought back moon rock to Earth. India wants to launch a satellite around Venus by 2024, the United Arab Emirates Mars programme, a cooperation agreement with ChinaRussia for the establishment of a lunar base). ESA, the European Union Space Agency, has around $21 \%$ of the world's space budget, and the EU Council has adopted the EU Space Strategy 2021-27, recognizing the economic importance of the sector and its necessity for Europe's self-determination. By developing a new, cost-effective rocket, Europe wants to compete with both old and new public agencies and the latest entrants, private companies (European Commission, 2016).

\section{ARTEMIS Programme Participants}

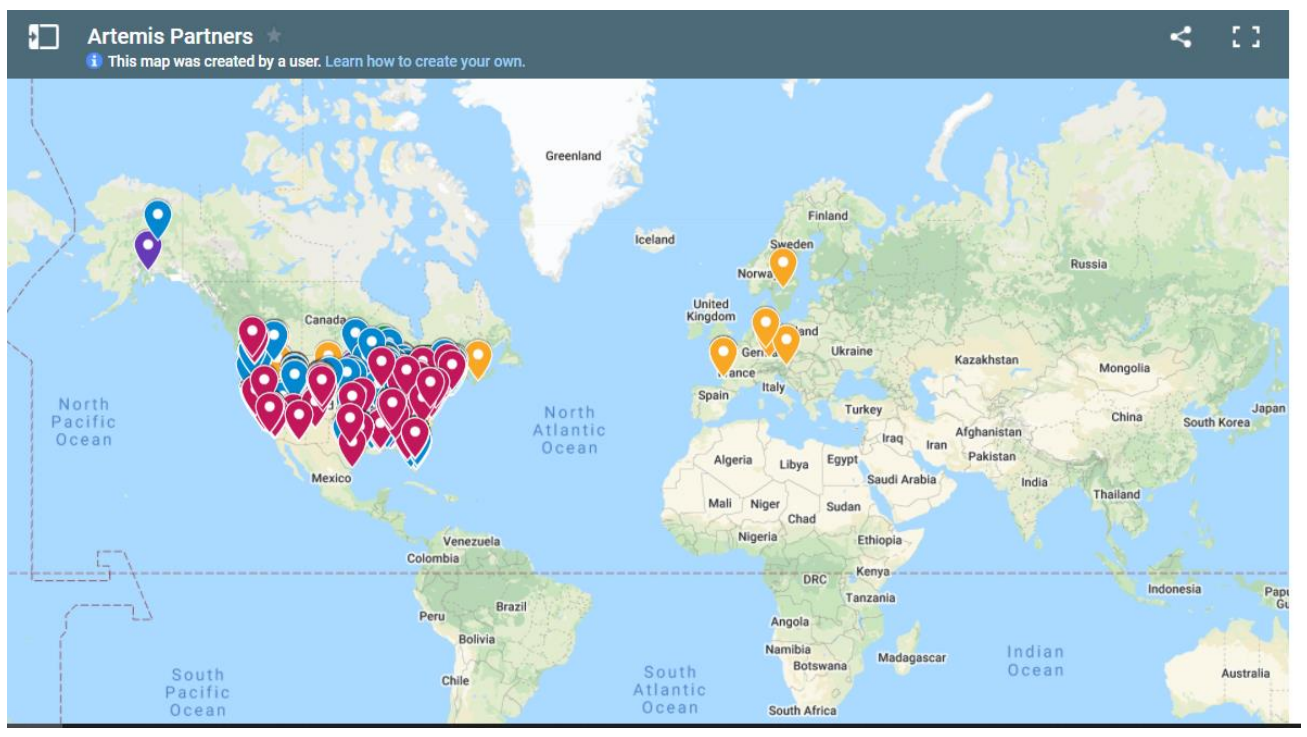

Source:(NASA, 2021)

A strategic aspect for the EU is not only to participate in space competition, but also to contribute to the holistic development of the high added-value industry in Europe and to involve the widest possible range of Member States. Hungary has joined this programme in 2015 as a full member of the ESA (ESA, 2021). The winner of this Framework Programme could be Airbus Defence and Space as ESA's main partner, which aims to develop Earth -based, research-based satellites for better understanding climate change and the biosphere (Airbus, 2021). In the meantime, NASA has set up new and more ambitious programs, one of the most important elements is of which the first human being on Mars can land. However, th is requires a significant increase in efficiency, which is now the main challenge for all industry players. In this, SpaceX, connected to Elon Musk, is at the forefront of all competitors. Europe (and thus Airbus) will probably be able to reuse its own space missile by the end or after the current Multiannual Financial Framework (MFF), while Boeing with Starliner will be able to reuse the cabin (NASA, 2020). 
Regardless of competition and some negative news in recent years on (Jones, 2018) (Kempe, 2021) space research, its human and financial capital intensity requires international cooperation. The ISS International Space Station is the most spectacular and most significant evidence of this, but currently several countries participate in the Artemis programme, although most of it are US companies and some European suppliers with different benefit. Orion, built for an unmanned moon landing, was fitted with Boeing server modules, which was created as a joint project of 10 ESA countries (Airbus, 2021).

Under the agreement, "Understanding on a cooperative framework for Large Civil Aircraft" the EU and the US will suspend punitive tariffs on products. The agreement of 2021 aims to resolve the dispute over state aid to Boeing and its European rival Airbus in peace. Boeing stated that the agreement would ensure that government aid would be market-oriented in the future. Refrain from R\&D funding as well as specific support (such as specific tax breaks) to their own producers that would harm the other side. Part of the agreement were: the offer financing to large civil aircraft producers on market terms; provide R\&D funding through an open and transparent process and make the results of fully government-funded R\&D widely available; collaborate on addressing non-market practices of third parties that may harm their respective large civil aircraft industries; establish a 'Working Group on Large Civil Aircraft' led by each side's respective Minister responsible for Trade. The two groups are expected to greatly relieve the agreement. The coronavirus crisis has slowed down international air traffic and severely increased many airlines, leading to numerous cancellations and postponements of aircraft orders. In addition, Boeing after the debacle around its most important 737 Max series, which was subjected to flight bans worldwide after two crashesover a year and a half, is already under attack anyway. The U.S. Group can use all support well. In addition, China is working at full speed and with high subsidies on the development of its own large commercial aircraft. Although the short-term threat may be low in view of the long-term advantage of Boeing and Airbus, the duopoly has a long-term risk of new competition in one of the most important foreign markets. The dispute between Boeing and Airbu s is the longest conflict in the history of the WTO. Since 2004, the US-EU dispute has been in progress before the Arbitration Courts of the Organisation. After the strong transatlantic upsets during the Trump era, the agreement reached is a major step towards rapprochement - even if it remains unclear how to resolve the actual dispute. This is mainly because the EU and the US have very different models of ind ustry support and are both convinced that theirs is the best and fairest.

\section{Summary}

Aerospace industry was one of those, which were hit the hardest by the consequences and restrictive measures due to the pandemic. The two biggest players, Boeing and Airbus have had a long-lasting dispute with a consequence of 11.5 billion USD punitive tariff on trades between the US and the EU, which hit not only the aerospace industry but also a wide range of the economy on both sides of the Atlantic. Further market fluctuations were caused by the tragic events, caused by technical errors in 737 MAX.

As some parts of the world are opening again, the economies are overcoming the shock, caused by the restrictive measures, were introduced worldwide, and the dispute was resolved (even though only on a temporary manner) between the US and the EU, strategists of companies can once again think on medium- and long-term objectives and strategies. 
Some determinant questions, which they have to address, are related to efficiency, sustainability measures, green technologies, safety and global cooperation. After the pandemic and as we can see the consequences of climate crises, the way which we are going to work, and travel will be changed drastically. The EU is a game changer with its comprehensive and global approach to green technologies and transportation, which will affect all participants of the global economies.

Those companies will have an advantage, which have been involved and dedicated to green and sustainable transition and have spent on related Research, Development, and Innovation activities for a longer time. As inflation is projected to remain on a high level, and fuel prices will further increase, these make producers to rethink their production strategies if they do not want to have further loose in demand. A healthy market needs several participants, so both flight manufacturers have a good future ahead of them, primarily not only in the production of passenger air transportation, but also in the field of space technology. 